\title{
Educational Reform and Practice of IE Major
}

\author{
High-level and Innovative Talents Training System
}

\author{
Yan Min \\ School of Electromechanical Engineering \\ Guangdong University of Technology \\ Guangzhou, China \\ Email: miny@gdut.edu.cn
}

\author{
Siyuan Cheng \\ School of Electromechanical Engineering \\ Guangdong University of Technology \\ Guangzhou, China \\ Email: imdesign@gdut.edu.cn
}

\begin{abstract}
Being an interdisciplinary subject of technology and management, IE (Industrial Engineering) deals with the optimization of complex system and process, and has its particular academic characteristic and feature. In the past thirty years, it has been widely applied in many fields of national economy and public administration of China. This paper presents the continuous educational reform and distinctive practice of high-level and innovative talents training system on IE major for undergraduates in GDUT (Guangdong University of Technology). Finally, this paper introduces the satisfied results of these reformations.
\end{abstract}

Keywords-industrial engineering; educational reform; college-enterprise union mode; curricular system

\section{INTRODUCTION}

IE is an interdisciplinary subject of technology and management. It combines the principles and methods of manufacturing engineering, management engineering and systems engineering (Fig.1).

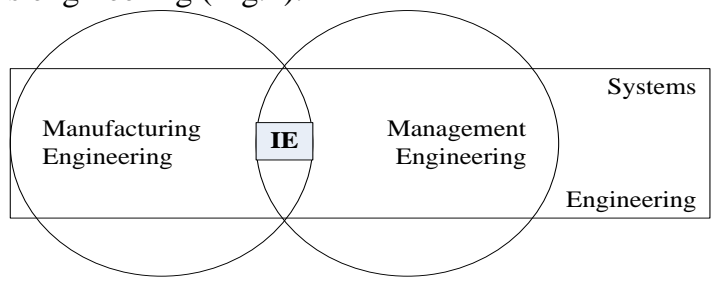

Figure 1. IE and relative subjects

\section{A. Brief Definition of Industrial Engineering}

Being one of the major branches of the engineering, industrial engineering (IE) deals with the optimization of complex system and process. It focuses on how to effectively operate the integrated system of people, material, equipment, energy and information by designing, developing, improving and implementing [1]. It improves labor productivity and economic efficiency with analysis, synthesis and usage of quantitative methods [2].

\section{B. Content Architecure of Industrial Engineering}

According to ANSI Z94.0-1982[3], from the point of subject, IE knowledge can be divided into seventeen subfields and there are four basic and critical aspects in them. They are shown in Fig.2

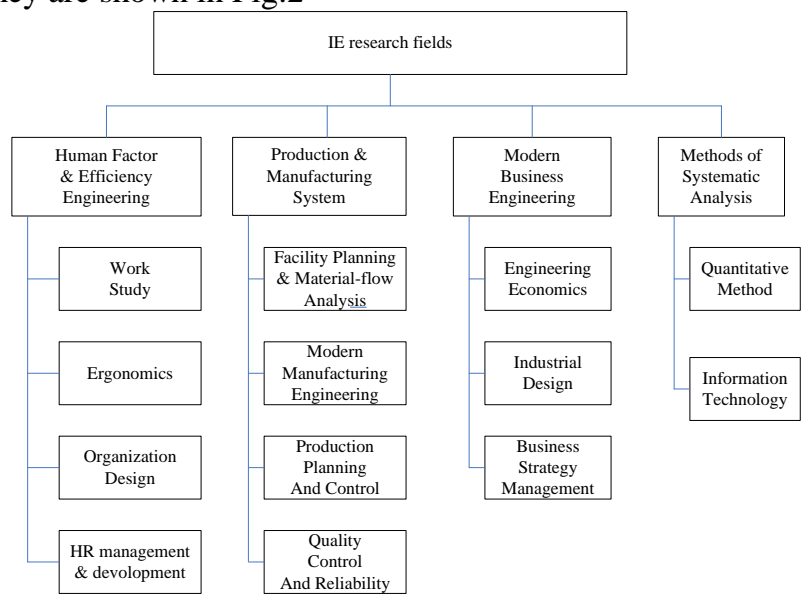

Figure 2. Research fields of IE

\section{CHALLENGES OF INDUSTRIAL ENGINEERING EDUCATION}

Nowadays IE faces more challenges and complex issues. Contemporary IE is considered one of the most rapid developing fields of engineering discipline. With emergence of complex science [4-5], industrial engineering has significantly expanded its application in the fields of industrial manufacturing, transportation, service, medicine and public administration.

Under such kind of condition, a high qualified IE talent should have the following capabilities [6]: 1) good background of academic knowledge and wide range of basic skills of IE theories and methods; 2) familiarity with IErelated theoretical methods and technology, such as such as systems engineering, IT technology, artificial intelligence technology, operations research, engineering economic analysis; 3) ability to discover, identify, clarify and resolve issues; 4) ability of systematic analysis, synthesis and integration; 5) ability of team cooperation, effective communication, professional ethics and responsibility; 6) comprehensive innovation capability; 7) lifelong learning capability, etc. 
It is a huge challenge to develop high-level and innovative talents to meet the social requirement and professional advancement. In the following sectors of this paper, it is presented the educational reform of high-level and innovative talents training system, and its practice of collegeenterprise union model.

\section{High-LEVEL AND INNOVATIVE TALENTS TRAINING SYSTEM}

\section{A. Current Situation}

GDUT is one of the earliest universities in China to set up the industrial engineering specialty in school of electromechanical engineering. It is also one of the first 22 universities that have been authorized to confer the Doctor's degree of IE discipline in China.

GDUT sets up the first IE specialty in Guangdong province, IE discipline of GDUT is famous in Guangdong, also has a good reputation all over the country.

Guangdong is one of the manufacturing centers in China, and also a major province of service industry. Under the background of transformation and upgrading of manufacturing industry and great development of service industry in Guangdong Province, industrial engineering has the irreplaceable particularity of other professions.

\section{B. Goal of Educational Reformation}

Industrial engineering is the only one engineering technology aimed at the efficiency and effectiveness of the system. The critical theory of IE is system optimization, the objective to implement the methods and technology of IE is to improve the actual production efficiency and service level of various production system and service systems.

The outstanding characteristic of IE professional training is the practical talents who can solve practical problems based on the actual system. The goal of educational reformation of IE students is to train high-level and innovative talents that meet the requirements of the society.

In order to achieve the above goal of reform, the training system of high level and innovative talents mainly includes the following specific contents: 1) to develop innovative training mode; 2) to develop better curriculum system; 3) to improve and perfect the cooperative training mechanism of college-enterprise union mode; 4) to strengthen international exchange and cooperation; 5) to supply more teaching-andlearning methods.

\section{Develop Inovative Trainning Mode}

The first step is to formulate and implement special cultivation plan for high level and innovative talents, there are two ways for this plan.

One way is the international cooperation and $2+2$ cooperative training projects with the foreign universities, including USA, France, Netherland, and the universities of Hong Kong and Macao region. These projects will help those students who are engaged in research work in the future, to enhance their academic attainment and academic ability.

Another one is college-enterprise union model. It will be discussed in detail later at the following sector of this paper.

\section{Optimize Curriculum System}

Taken the aim at developing high qualified IE talents, the curriculum of IE major includes following aspects shown in Table 1.

TABLE 1 CURRICUlAR SYSTEM OF IE MAJOR FOR UNDERGRADUATE STUDENT

\begin{tabular}{|c|c|}
\hline Core Curriculum & Course Area \\
\hline Foundation & $\begin{array}{l}\text { Mathematics, Physics, English, } \\
\text { Applied Mathematics, , } \\
\text { Humanity Social Science, etc. }\end{array}$ \\
\hline Engineering & $\begin{array}{l}\text { Current, Electronic Engineering, } \\
\text { Mechanical Engineering, etc. }\end{array}$ \\
\hline $\begin{array}{l}\text { Manufacturing } \\
\text { Management } \\
\text { and control }\end{array}$ & $\begin{array}{l}\text { Fundamental IE } \\
\text { Manufacturing Planning and control, } \\
\text { Ergonomics, } \\
\text { Modern Quality Engineering, etc. }\end{array}$ \\
\hline $\begin{array}{l}\text { Information } \\
\text { Technology }\end{array}$ & $\begin{array}{l}\text { C language programming } \\
\text { The principle and application of database } \\
\text { Information system } \\
\text { Computer network } \\
\text { Integrated design of information system, etc. }\end{array}$ \\
\hline $\begin{array}{l}\text { Modern } \\
\text { Logistics } \\
\text { Management }\end{array}$ & $\begin{array}{l}\text { Fundamental Management } \\
\text { System engineering } \\
\text { Logistics management } \\
\text { The technology and application } \\
\text { of the Internet of things } \\
\text { Finance and cost management } \\
\text { Engineering Economics, etc. }\end{array}$ \\
\hline $\begin{array}{c}\text { System } \\
\text { modeling } \\
\text { and simulation }\end{array}$ & $\begin{array}{l}\text { Operations Research } \\
\text { Innovation method } \\
\text { Statistics, Design of experiment } \\
\text { System simulation technology } \\
\text { Facilities layout and logistics analysis, etc. }\end{array}$ \\
\hline Tools of IE & $\begin{array}{l}\text { CAD/CAM, } \\
\text { Simulation Computer Application, Statistics } \\
\text { Computer Application, ERP system, etc. }\end{array}$ \\
\hline Additional Options & $\begin{array}{l}\text { Safety and equipment management, } \\
\text { Intelligence transportation, } \\
\text { Human Resource } \\
\text { Emergency Management, } \\
\text { Knowledge Management, } \\
\text { Advanced Manufacturing Technology, etc. }\end{array}$ \\
\hline Practice & $\begin{array}{l}\text { Curricular Project, Working Practice, } \\
\text { Multi-purpose Engineering Practice, } \\
\text { Diploma Project, etc. }\end{array}$ \\
\hline
\end{tabular}

Design a new curriculum system, build a platform + modular curriculum system based on knowledge structure of the IE discipline.

In addition to the current curriculum system that has been developed for production management and optimization of traditional manufacturing industry and service industry, the amount of courses from the fields of information technology, logistics and transportation management, system modeling and simulation technology, innovation theory and methods are dramatically increased in the new curriculum system [7].

The new curriculum system is better to conform to the complex system such as modern manufacturing industry, modern logistics management, intelligent transportation 
system, modern service industry that involve more advanced automation and AI technologies

The objective of new curriculum system to increase students' comprehensive ability, on the basis of the traditional IE skills, students are able to choose 1 or 2 optional modules for continuous learning in order to realize the diversified training mode of "one specialty with multi-mode and multiskill".

Basing on the traditional knowledge-centric explainingoriented teaching mode, some new teaching methods were introduced, such as heuristic teaching, research teaching, cooperative teaching, group learning, problem-based learning [8-11].

\section{E. College-Enterprise Union Mode}

Since inception in 1999, we have implemented the explosion in the undergraduate education of IE major. That is to complete working practice and diploma project in enterprise.

With the experience and achievements on practical works in these years, we have adopted our training mode which is similar to it in prestigious international universities. Since 2013, we have implemented the college-enterprise union training mode, which is briefly called $3+1$ mode. Both 3 and 1 are in the time dimension.

Under this $3+1$ mode, during the three years from freshman to junior, the students will complete all the specialized theoretical courses and practical courses in the University. As senior, students will spend a full academic year in enterprise and work on the project of the enterprises. We call it the project-driving learning and practice.

In order to implement and prove college-enterprise union mode, we have spent a lot of time on the following three tasks.

First, setup an integrated practical system which consists of experimental software platform, configurable manufacturing line for teaching and case base of multi industry and multi topic.

Second, design a set of selection and competition methods. Enterprises put forward their requirement and set up projects, Students and enterprises confirm their intentions through two-way selection, finally agreements will be signed by university, students and enterprises.

Third, construct cooperative education mechanism between university and enterprise, promote the comprehensive cooperation with relevant enterprises so as to achieve a positive interaction between teaching, research and production.

The diagram of cooperative platform is shown as Fig.3

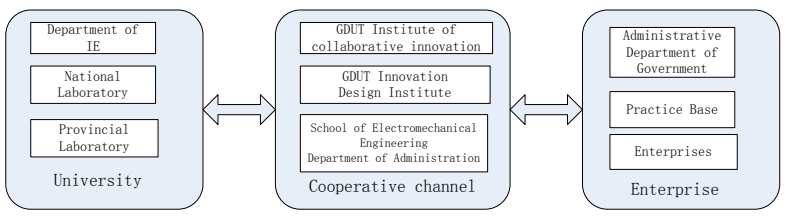

Figure 3. Diagram of college-enterprise union platform
In order to ensure the quality of college-enterprise union training, every student is assigned two tutors who are professional teacher of university and supervisor of enterprise. Both of tutors will follow the practice process, discuss with the managers of enterprise and student himself/herself to determine the task, content and schedule of the practice, give their advice and support to student, and they are also the coordinators and communicators between university and enterprise.

\section{CONCLUSION}

This paper presents a continuous educational reformation of IE major in GDUT. In the past decade, there are many efforts on improving the quality of IE academic education and practice that are focused in three aspects, namely, curricular system, teaching method and learning mode, the practice of college-enterprise union training mode.

The continuous reformation has achieved remarkable results in the past years. It is helpfully that students can make career planning earlier and better, there are opportunities that make it easier for students to enter their favorite businesses. Meanwhile, they have significantly improved their abilities of profession, research, practical and innovation. The university could establish a strict, standardized and efficient closed loop management system for teaching quality. A longterm and sustained strategic cooperative relationship with enterprises is a powerful factor, there is a rapid and comprehensive development of IE discipline through the reform. The relevant achievements include the cooperative education between university and society, the teaching team, the teaching methods, the construction of the core curriculum group, the construction of practical teaching. The enterprises get the high-qualified talents which meet their requirements,

IE could make enterprises get higher productivity, higher quality product, lower cost and better effectiveness and efficiency.

The continuous educational reform and practice has transformed the approach from "teaching" to "learning", it makes good combination of theory and practice in IE education. By implementing these reform exploration, the quality of education of IE major would be further improved in the future.

\section{ACKNOWLEDGMENT}

This paper is funded by the educational reform projects of Guangdong province, they are: (1) Comprehensive reform pilot project of industrial engineering discipline; (2) Teaching team construction project of mechanical design specialty. The authors are grateful for the support of the above projects.

\section{REFERENCES}

[1] G Salvendy. Hand book of industrial engineering. JOHN WILEY\&SONS Inc., 1982.

[2] Philips E. Hicks. Introduction to industrial engineering. IIE, 1998. 
[3] Institute of Industrial Engineers (1981- ). Industrial engineering terminology: a revision of ANSI Z94.0-1982: an American national standard, approved July 10, 1989, Industrial Engineering and Management Press, 1990.

[4] Qian X S, Yu J Y, Dai R W. A new discipline of science-The study of open complex giant system and its methodology, System for Engineering and Electronics, Volume 4, no.2, pp 2-12,1983

[5] Zhang M H, Yuan Z P. Factor Analysis of Enterprise Performance Based on Complex Science Management and Synergetics, Wireless Communications, Networking and Mobile Computing, 2008. WiCOM '08. 4th International Conference, pp 1-4

[6] Wei Y M, Fan Y, Xu W X. The Past, Present and Future of Industrial Engineering, Nankai Business Review, No.2, pp 19-21, 1983

[7] Liang Xuemei, Yan Min, Yang Jie. TRIZ-oriented Application of Innovation Methods and Construction of Collaborative Innovation System[C]. July 2016, TRIZfest 2016 Procedding, pp. 393-400.
[8] Min Y. Innovative thinking in classroom instruction design and practice, Journal of Guangdong University of Technology (Social Science Edition), Vol 7 suppl, pp 102-103, 2007.

[9] Zhou J P, Su P, Rao Z, Fan C M. Research-oriented simulation experimental system for industrial engineering, Research and Exploration of Laboratory, Vol 30, no.8, pp 267-270,274, 2011

[10] MIN Yan, SU Ping, ZHOU Jin-ping, An Exploration of Reformation in Undergraduate Education of Industrial Engineering Major, 2013 Conference on Education Teaching in College and University, Oct 2013, pp. 966-970.

[11] Yan Ye. Teaching Design and Practice of Intersection Courses, 2011 The Conference on Information Technology and Education Teaching, Wuhan, 2011, pp. 4263-4266. 